\title{
Implementation of HIV and AIDS Management Policies in the City of Bandung
}

\author{
Hadi Prabowo ${ }^{1}$, Ismail ${ }^{2}$, Agus Fatoni $^{3}$ \\ 1,2,3 Institut Pemerintahan Dalam Negeri (IPDN), Indonesia \\ Email: hadi.prabowo@gmail.com
}

\begin{abstract}
Patients with HIV and AIDS in Bandung are problems that need treatment so that the number of people with HIV and AIDS decreases. This study aims to find out how the implementation of HIV and AIDS prevention policies in the city of Bandung and the driving and inhibiting factors by using the theory of Van Metter and Van Horn policy implementation. This study uses qualitative methods with a purposive sampling technique in determining informants and uses triangulation techniques in data analysis. The results of the study revealed that the implementation of HIV and AIDS prevention policies in the city of Bandung is still not going well because of the factors that have not been externally driven by a boost program, lack of public understanding and the absence of HIV AIDS drugs to cure the disease completely.
\end{abstract}

Keywords: policy implementation, management policy, HIV, AIDS.

\section{A. INTRODUCTION}

Sexually transmitted diseases continue to be a threat to the world's population. Eradication of infectious diseases that are part of healthy development is the concern of every country. One infectious disease that is the focus of attention is HIV and AIDS. HIV and AIDS are a type of sexually transmitted disease due to risky sexual behavior (PHS) (Fritantus \& Rukminingsi, 2015).

HIV (Human immunodeficiency virus) is a virus that causes AIDS (Acquired Immunodeficiency Syndrome). AIDS (acquired immunodeficiency syndrome) is a collection of symptoms of reduced self-defense ability caused by the entry of the HIV virus in a person's body. People with HIV and AIDS are people who have been infected with the HIV virus. The HIV virus can be transmitted through free sexual contact or called Sexually Transmitted Infection which is transmitted through sexual intercourse, anal/sexual intercourse through the anus, and oral / by mouth, and can be transmitted as a result of one's dependence on consuming Narcotics, Psychotropics, and Substances Addictive (NAPZA) which will affect the body especially the brain and central nervous system, causing physical health, psychological and social functioning.

Bandung City is one of the largest metropolitan cities in Indonesia, it is also inseparable from the problems of public health, especially regarding the social problems of HIV and AIDS. The Surabaya City Government is fully aware that the development of HIV and AIDS transmission and spread shows an increasingly alarming trend where the number of cases of HIV and AIDS continues to increase in the City of Bandung. 
In this connection, in order to provide legal certainty and protection for every effort to combat HIV and AIDS in the city of Surabaya. The City Government of Surabaya then forms the legal basis for all parties involved in the implementation of HIV and AIDS prevention and control in the city of Bandung, namely the Bandung Regional Regulation No. 12 of 2015 concerning Prevention of the Abuse of Psychotropic Narcotics and Other Addictive Substances and the Prevention of Human Immunodeficiency Virus / Acquired Immune Deficiency Syndrome.

In addition, the Government of the City of Bandung also formed a non-structural and multisectoral government agency that handles HIV and AIDS issues in the regions in collaboration with the Health Office namely the HIV AIDS Prevention and Control Working Group and the AIDS Concerned Citizens Forum. But in the implementation of HIV and AIDS prevention policies in the city of Bandung is still not going well. This is evidenced by a large number of new HIV and AIDS sufferers and has even increased from year to year.

According to Anderson (in Islamy, 2007) said that public policies are those policies developed by governmental bodies and officials. According to Dunn (Edi, 2008), there are three forms of public policy analysis models, namely the Prospective model, the Retrospective model, and the Integrative model. The role of stakeholders in this policy also needs to be analyzed, although this policy can be interpreted as a preventive attitude of the Bandung City government in dealing with the HIV and AIDS epidemic.

There have been many studies on the implementation of HIV and AIDS prevention policies in Indonesia (Sagala et al., 2013; Fritantus \& Rukminingsi, 2015; Purnomo, 2015; Ningtyas, 2015; Gani, 2016; Marthin et al., 2017; Siti, 2017). However, no research has been carried out on the implementation of HIV and AIDS prevention policies in the city of Bandung, so this research has novelty value and has significance on scientific findings.

This study aims to analyze the implementation of HIV and AIDS prevention policies in the city of Bandung and the factors that encourage and hinder the implementation of HIV and AIDS response policies in the city of Bandung.

\section{B. LITERATURE REVIEW}

Basically policy definitions have different meanings depending on where the emphasis is given. Public policy can mean a series of instructions from decision-makers to policy implementers that explain the goals and ways to achieve these goals (Winarno, 2007). The nature of public policy as a direction of action can be better understood if broken down into several categories, namely: policy demands, policy decisions, policy statements, policy outcomes, and policy impacts. A policy that has been made will be implemented later and it is hoped that the implementation of public policy can be successful so as to achieve the desired goals. 
Implementation Study is a study of policy studies that lead to the implementation process of policy. According to Anderson (in Agustino, 2014), revealed that public policy is a series of activities that have a specific purpose/goal that is followed and carried out by an actor or group of actors who are related to a problem or a matter of concern. In practice, policy implementation is a process that is so complex that it is often politically charged with the intervention of various interests.

According to the Theory of Policy Implementation Process according to Van Meter and Horn (in Winarno, 2002), the factors that support policy implementation, namely the measures and objectives of the policy, sources of policy, communication between organizations and implementation activities, characteristics of agencies implementing agencies, economic, social and political conditions, tendencies of implementers. Inhibiting the policy implementation according to Sunggono (1994), policy implementation has several inhibiting factors, namely the content of the policy, information, support, and potential sharing.

\section{RESEARCH METHODS}

This type of research is a descriptive study with a qualitative approach (Afrizal, 2014). According to Moleong (2000), the purpose of this descriptive research is a study that is described in the form of word words and not numbers so that what is collected is the key to what has been studied. Bogdan \& Taylor (in Moleong, 2000), defines qualitative methods as research procedures that produce descriptive data in the form of written or oral words from people and observable behavior. The use of descriptive research with a qualitative approach is seen as more supportive and meaningful in absorbing issues related to the focus of research.

The focus of this study includes the implementation of HIV and AIDS prevention policies in the city of Bandung and the factors that influence it. Stakeholders in HIV and AIDS prevention policies in the city of Bandung, among others, consist of secondary stakeholders and primary stakeholders, and supporting factors and inhibiting factors in HIV and AIDS prevention policies in Bandung. Research locations in the city of Bandung and research sites at the Bandung City AIDS Commission, the HIV AIDS Prevention Working Group, and Non-Governmental Organizations.

Data collection is done through interviews, observation, and documentation. The research instruments were the researchers themselves, interview guidelines and supporting tools. The data analysis model in this research is an interactive model. In the interactive analysis, the data that has been collected is read, studied and analyzed, then abstraction is made. After the abstraction, then the data is arranged in one unit while checking the validity of the data. The final step taken is the interpretation of the data. 


\section{RESULTS AND DISCUSSION}

\section{Implementation of HIV and AIDS Response Policies in the Vity of Bandung}

In an effort to reduce and control the spread of the HIV and AIDS virus in the city of Bandung, the initial strategic step before carrying out policy execution in the field, the Government through KPA as the coordinator of the response along with the policy stakeholders undertook the preparation and formation of the HIV and AIDS Prevention Plan within a period of 5 years. The preparation of this Strategic Plan involves many experts, practitioners, as well as policy activists in the hope that the policies determined later can be realized according to the existing potential.

This research was carried out in the city of Bandung in order to find out the implementation of HIV and AIDS prevention policies in the city of Bandung based on Bandung Regional Regulation Number 12 of 2015. Using the Van Metter and Van Horn grand theory which consists of 6 dimensions, namely the measures and objectives of the policy, sources policy sources, communication between organizations and implementation activities, characteristics of implementing agencies, economic, social and political conditions, tendencies of implementers.

The size and purpose of Bandung City Regulation Number 12 of 2015 are said to be too idealistic. The first and second points of the purpose of the Bandung City Regional Regulation regarding the elimination of new HIV and AIDS viruses and eliminating deaths caused by HIV and AIDS will be difficult to achieve because for HIV and AIDS until now there has not been found a drug that can truly cure completely.

Financial resources are an obstacle to HIV and AIDS prevention efforts in implementing programs, namely socialization. This is proof that not all junior high, high school, and tertiary level schools get information about HIV and AIDS. Sometimes the school itself asks government agencies to do socialization with funds from the school.

The Health Office, KPA (AIDS Commission) and Non-Governmental Organizations on HIV AIDS in the city of Bandung formed an ODHA community in which there is an activity with creativity to improve the quality of life of the PLWHA, besides that the Health Office, KPA and NGOs also conducting socialization to the public about understanding HIV AIDS. However, the actions taken have not been able to achieve the objectives of PERDA No. 4 of 2015 concerning the implementation of HIV AIDS prevention efforts in the city of Bandung about eliminating discrimination against PLWHA. In the treatment of PLWHA, there are still PLHIVs who are experiencing despair so that PLHIV does not carry out the routine treatment which in the end many deaths are caused by the HIV AIDS virus. Discrimination is not even done only by people who do not know about the HIV AIDS virus, but there are still people who work or sit in health institutions who discriminate. Besides government agencies to minimize acts of discrimination from the community, people who are HIV positive are protected by the name and address privacy by the institution as the executor of the HIV AIDS prevention efforts. 
Coordination is still not going well because there is an HIV screening program at the Puskesmas that has not yet run the program. The HIV screening targets pregnant women, but when pregnant women check the contents, the HIV screening is not carried out so that the pregnant woman checks HIV in the hospital.

The attitude of the implementers in closing places that are very vulnerable in terms of HIV and AIDS transmission in order to achieve the goals of the Regional Regulation of the City of Bandung Number 12 of 2015 can be interpreted that the closure of entertainment venues in the city of Bandung will be difficult to abolish due to several factors, namely economic factors for workers in the place, while the government itself cannot guarantee the economic needs of the community, the second factor is that entertainment places contribute financially in the form of tax payments and the third factor is precisely the closure of the place will make the spread of WTS will difficult to be monitored and monitored by the government. In spite of the difficulty in removing these places, the institutions that carry out HIV AIDS prevention efforts in the city of Bandung conduct HIV and AIDS screening tests in these places to prevent the addition of new HIV AIDS viruses, although the checking period is not done routinely, in 1 year approximately two checks.

The condition of the economic environment will have an impact on one's social life. Because with the increasingly high economic needs and the absence of the government to make programs that are external impetus to realize the goals of the Regional Regulation of the City of Bandung Number 12 of 2015 on HIV AIDS prevention in the city of Bandung which will result in a person fulfilling his economic needs by doing very vulnerable work in terms of HIV AIDS transmission such as transsexuals and WTS. The LGBT community is also a result of adverse social environmental conditions. The economy is still low will affect the level of education so that it will also affect one's mindset in the society. But from the results of interviews with other informants, the very basic thing is from the faith factor of each individual or group.

\section{Supporting and Inhibiting Factors for Implementing HIV and AIDS Control Policies in the City of Bandung}

The implementation of the policy on countermeasures has the support of various institutions, both government and non-government institutions that are members of the working group. The support of NGOs who have long overseen the development of HIV and AIDS in the city of Bandung has greatly assisted various countermeasures programs that have been promoted by the government.

In the case of the need for mapping hotspots of key groups from areas or points where there are suspected to be vulnerable interactions, there is a risk of HIV and AIDS transmission through sexual transmission and networks to the grassroots are needed. The existence of a network built by the Working Group is very helpful in the prevention program being implemented by the Government of the City of Bandung. So that assis- 
tance can be made to groups that are truly the policy targets.

The facilities and infrastructure which are notes to support the success of the policy gradually have also been well fulfilled. This can be seen from the facilities dedicated to HIV and AIDS testing that have improved both in quality and quantity.

The quality in question is the increase in practitioners and experts who are directly involved in prevention activities such as doctors, BNK, AIDS activists, etc. both from the quality and quantity have improved. Likewise, infrastructure such as mobile clinic facilities that have been added, medicines that are actually free, and VCT and STI health facilities are held in almost every hospital and some Puskesmas in Bandung. This is a supporting factor for HIV and AIDS prevention policies in the city of Bandung.

Although it is normative, the lack of coordination between stakeholders makes the realization of the program less than optimal. This makes the obstacles that until now still can not be found, so many miss-communication and understanding are found, especially at the technical level, although in essence, stakeholders support each other.

The next limiting factor is the level of understanding of the risk community and the general public regarding STI or reproductive health education which is still very minimal. Therefore, there is a need for a variety of campaign and outreach activities to be able to touch wider community groups and understand them.

The lack of condom use, especially in risk groups and key populations such as customers, FSW, CSWs, transvestites and other key groups is what makes HIV and AIDS in Bandung difficult to suppress. This is very difficult to handle because of the limitations of implementing the policy except by raising awareness and understanding of the group to use condoms.

Mobility of at-risk groups in and out of the city of Bandung, both from outside the Bandung area and between localizations to other brothels in the area of the City of Bandung makes particular attention over the implementation of HIV and AIDS prevention, because of the high or low level of mobility of groups at risk of contracting and transmitting HIV / AIDS or in the case of this was said by prostitutes such as commercial sex workers and customers making challenges as well as inhibiting factors for overcoming HIV / AIDS in the city of Bandung.

Detection of CSWs by KPA and NGOs through Facebook and other social networks led to the development of covert prostitution activities that are known to the profession as well as varied housewives, shopkeepers, masseuses, campus chickens, sales, and others. The number of hotels and inns in the city of Bandung that provide rooms without having to show a marriage certificate / KTP along with their address, so customers do not need to go to a localization that is outside the area, this clearly adds to the long list of levels of difficulty in outreach and accompaniment to change risk sex behavior by KPA or other stakeholders. 


\section{CONCLUSION}

HIV and AIDS prevention policies carried out by the Bandung City Government have been implemented well but are still not optimal, with the support of conducive environmental conditions, high commitment both executive, legislative, and community as evidenced by the stipulation of policies in the form of Bandung City Regulation Number 12 Year 2015 Concerning HIV and AIDS prevention in the city of Bandung as well as pioneering policies in other forms and countermeasures that involve many stakeholders in its implementation.

The implementation of HIV and AIDS prevention policies in the city of Bandung receives support from a variety of institutions both from government and nongovernment institutions that are members of the working group. The existence of a network built by the Working Group is very helpful in the prevention program that is being carried out by the City Government of Bandung. So that assistance can be made to groups that are truly the policy targets. Facilities and infrastructure which incidentally support the success of the policy have also been gradually well fulfilled. This can be seen from the facilities dedicated to HIV and AIDS testing that have improved both in quality and quantity.

Lack of coordination between stakeholders makes the realization of the program less than the maximum to be implemented and the level of understanding of the risk community and the general public regarding STI or reproductive health education is still very minimal. The lack of condom use, especially in risk groups and key populations such as customers, FSW, CSWs, transvestites and other key groups is what makes HIV and AIDS in Bandung difficult to suppress.

\section{REFERENCES}

1. Afrizal. (2014). Metodolgi Penelitian Kualitatif. Bandung: Alfabeta.

2. Agustino, L. (2014). Dasar-dasar Kebijakan Publik. Bandung: Alfabeta.

3. Edi, S. (2008). Analisis Kebijakan Publik. Bandung: Alfabeta.

4. Fritantus, Y., \& Rukminingsih, N. (2015). Implementasi Kebijakan Penanggulangan HIV dan AIDS di Kota Surabaya (Kajian Peraturan Daerah Kota Surabaya Nomor 4 Tahun 2013, Studi Kasus di Puskesmas Putat Jaya, Kota Surabaya). JPAP: Jurnal Penelitian Administrasi Publik, 1(01).

5. Gani, H. A. (2016). Analisis Kebijakan Peraturan Bupati Jember Nomor 2 Tahun 2014 Tentang Pencegahan dan Penanggulangan HIV/AIDS di Kabupaten Jember. STOMATOGNATIC-Jurnal Kedokteran Gigi, 12(2), 54-60.

6. Islamy, M. I. 2007. Prinsip-Prinsip Perumusan Kebijaksanaan Negara. Jakarta: Bumi Aksara.

7. Marthin, W. B., Kandou, G. D., \& Tucunan, A. A. (2017). Analisis Pelaksanaan Kebijakan Program Pencegahan Dan Penanggulangan HIV/AIDs di Komisi Penanggulangan Aids (Kpa) Kota Bitung. KESMAS, 6(3). 
8. Moleong, L. J. (2014). Metodologi Penelitian Kualitatif. Bandung: Remaja Rosdakarya.

9. Ningtyas, B. K., Makhmudah, M., \& Hayyuning, J. (2015). Strategi Implementasi Kebijakan Penanggulangan Penyakit Menular HIV/AIDS di Kabupaten Jember Dalam Upaya Percepatan Pencapaian Millenium Development Goals 2015. Fakultas Ilmu Sosial dan Ilmu Politik Universitas Brawijaya.

10. Peraturan Daerah Kota Bandung Nomor 12 Tahun 2015 Tentang Pencegahan Penyalahgunaan Narkotika Psikotropika dan Zat Adiktif Lainnya dan Penanggulangan Human Immunodeficiency Virus/Acquired Immune Deficiency Syndrome.

11. Purnomo, D. (2015). Analisis Kebijakan Penanggulangan HIV dan AIDS di Kota Bandung (Studi Pelaksanaan Peraturan Daerah Nomor 14 Tahun 2008 Kota Bandung). Jurnal Administrasi Publik, 3(1), 42-48.

12. Sagala, A. H., Suwitri, S., \& Santoso, S. (2013). Implementasi Kebijakan Penanggulangan HIV dan AIDS di Jawa Tengah (Kajian Peraturan Daerah Provinsi Jawa Tengah Nomor 5 Tahun 2009). Journal of Public Policy and Management Review, 2(4), 116126.

13. Siti, W. (2017). Implementasi Kebijakan Pencegahan dan Penanggulangan Human Immunodeficiency Virus dan Aquired Immune Deficiency Syndrome (HIVIAIDS) di Kota Surakarta (Doctoral dissertation, Universitas Sebelas Maret).

14. Sunggono, B. (1994). Hukum dan Kebijaksanaan Publik. Jakarta: Sinar Grafika.

15. Winarno, B. (2002). Kebijakan dan Proses Kebijakan Publik. Yogyakarta: Media Pressindo. 